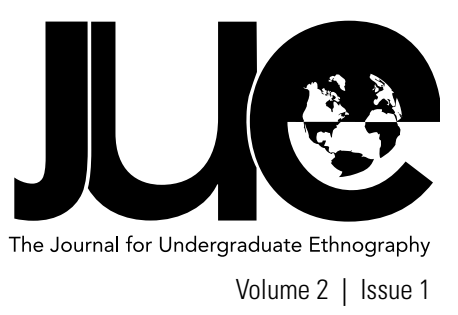

\title{
Street Vendors in the Global City: Exploring Genoa's Informal Economy
}

\author{
Joseph S. DeLuca
}

John Jay College of Criminal Justice, joseph.deluca@jjay.cuny.edu

\begin{abstract}
(2) any given nice afternoon or early evening, it is not an uncommon site to see some Senegalese, Moroccan, or other North African street vendors on Via XX Settembre, in Piazza De Ferrari, or by the Principe train station on Via Pré or Via Del Campo in Genoa, Italy. Lined up along the sidewalk or roaming tightly confined market areas, and always on the lookout for police presence, they represent recurring actors on the complex stage of globalization in the global city. These niches in the informal economy represent a growing trend in the modern city. Who exactly are these people? How has the global city enhanced said roles? Why have these roles come about? And how do these people deal with the inevitable challenges they face? Looking at Genoa via the idiosyncratic framework of New York City's established informal market, this study of a growing, culturally infused city in the 21st century hopes-through the use of historical context, naturalistic observations, and interviews-to humanize these individuals' experiences and give a look into their complex lives.
\end{abstract}

Keywords: globalization, street vendors, global city, urban life, immigration 


\section{choice to leave one's home country is often well thought out and a result of a lot of stressful decisions. It is a complicated process, fraught with uncertainties and anxieties. Will I make it? Where will I live? Will I be deported? Will I ever be able to return home again?}

${ }^{1}$ In this article, I have changed the names of people I mention in order to protect their confidentiality

\section{INTRODUCTION}

The influx of a large amount of immigrants anywhere poses many problems for the host country, but also for the immigrants themselves. In significant parts of Africa, political corruption, war, and lack of opportunity, combined with threats of poverty, force many people to immigrate into Europe. The goal in the end is the same for most immigrants: earn as much money as possible and send a portion to family back home. Many find it difficult at first to survive, however, and a lot resort to work in the informal economy. For most, though, these occupations tend to work out well for them financially.

Many African nations have indeed felt the aftershocks of post-industrialization. In a continent primarily reliant on agriculture and contingent weather patterns, globalization has provided temporary opportunities for work, but long-term implications for African economies. It is currently estimated that about sixty-five percent of Africans rely on agriculture for a living (International Food Policy Institute 2009). Over the last several decades, however, Morocco has emerged as a leader in the offshoring sector. Partly due to its geographical closeness to Europe and relatively stable climate, it has become a hub for cheap labor (Belhaj 2009). Senegal has concurrently seen an influx of multinational corporations and foreign investments, leading to a reduction-and in some cases, a complete exclusion - of smallholder suppliers within the horticulture industry (Colen et al. 2009). This introduction of vertical integration has further perpetuated the existence of unskilled labor and immigration.

Most of these immigrants come with the idea to stay for a few years and then return to their country, but this frequently turns out to be harder than previously thought. Whether it is to North 
America or to Europe, the route immigrants must take to and from Africa is often a perilous journey. Traversing the ocean, watercrafts carrying immigrants are often loaded well beyond capacity, unequipped with lifesaving equipment, and manned by inexperienced sailors. In Italy alone, over 13,000 bodies have been recovered in the last decade in the Mediterranean, due to shipwrecks (Voice of America 2009).

The choice to leave one's home country is often well thought out and a result of a lot of stressful decisions. It is a complicated process, fraught with uncertainties and anxieties. Will I make it? Where will I live? Will I be deported? Will I ever be able to return home again? In the end-to these men, women, and children-a chance of earning more money, and subsequently a better life for them and their family is well worth the danger of trying. For many of these immigrants, there is nothing left to lose. As one desperate Libyan refugee put it (after his ship sank and he swam to shore), "If they send me back, they send me back...I don't care. I've already lost everything" (Abrahamson 2004, 52).

Most have a conditioned fear of strangers when they do finally make it. Among my observations and interviews, I could always see the fear in the eyes of the vendor, his eyes darting left and right for police presence, his timidity and short responses, and his reserved nature. Although vendors conveyed to me that deportations among them are rare, the criminalization and discrimination of these individuals, as well as the pressure they put upon themselves to be successful, culminates into a day-today anxiety, and general distrust of others. A rare incident, but shocking nonetheless, in December 2011 validated these fears: An Italian citizen went on a shooting spree in a crowded market area, killing two Senegalese street vendors, and wounding three others, before killing himself (Kington 2011). One hopes this will be an isolated incident, but with rising tensions in Italy (and around the world) surrounding unemployment and other social, economic, and political woes, will the immigrant street vendor become the inevitable scapegoat?

In the marketplace, these men (and a few women) predominantly sell counterfeit goods at a cheap price. Although almost every city requires one to have a license to sell on the streets, these immigrants often do not due to their illegality. Compound this with the countless trademark and copyright infringements committed by these sellers, and it is easy to see how these men and women accumulate enemies.

The life of an immigrant street vendor is a complex one. Albeit, it is a relatable one for most: The need to support your family, even if that means traveling to another country to live and work, resonates deeply on a human level. Unfortunately, the uncertainties that follow these immigrants are ubiquitous. With said uncertainties come a developed characteristic of hypervigilance, but at the same time, a remarkable level of resilience and hope. The globalized nature of the 21 st century has transcended the idea of this nomadic wanderer. These vendors setup intricate networks among their peers, maintain connections back home, and make a living in the informal economy. The subculture created in the informal economy becomes a culture in and of itself. These people know what they are doing, and they often do it quite well. In a growing global city such as Genoa, these informal roles and communities are slowly emerging.

\section{RESEARCH METHOD AND SETTING}

Geographically speaking, it is not surprising that many North African immigrants end up in Genoa. For North Africans coming to Europe the first stop has been the bottom of the boot most recently, via Lampedusa, in the region of Sicily. During the summer of 2010 alone, nearly six thousand immigrants migrated here-more than the local population of Lampedusa itself (Pisa 2011). Immigrants coming to Europe then make their way up the peninsula. In addition, with Genoa being a port city, it provides easy access via the coast, and short train rides to several other global cities. Many immigrants to Italy, for example, find homes in places like Florence and Rome.

This research was conducted during June 2011, in Genoa, Italy. Notepad in hand, I conducted many daily observations throughout the city. My main areas of focus included the busy city center near Piazza De Ferrari and the historical section; my concentration shifted further east during weekend market days. Understandably perturbed by a foreigner with a notepad, detailed interviews were hard to come by on my own. However, I was able to make small talk regarding their home country and family, how long they've been in Genoa, and where their products were from, as well observe the actions of many vendors. On nice days, late morning to afternoon seemed the most opportune times to see these vendors in action. Police presence occasionally disrupted the flow of the informal economy in this crowded area, but they always assumed their positions again. These vendors, being in a vulnerable position due to their illegality, were always told beforehand of the study's purpose, as well as the ethical procedures. The confidentiality of their personal information was ensured, and pseudonyms were used when asked.

As the month progressed, and with the help of an expert on the topic (and friend of many of the vendors)-Professor of 
Anthropology at the University of Genoa, Dr. Roberto Alzetta-I was able to delve into more personal details with these vendors. Topics regarding feelings about their undocumented status, racism, sales and remittances sent back home, family, living conditions, and culture and religion were explored. So as not to impede on the potential sales of these individuals, I conducted three such "full" interviews, ranging from 15-20 minutes, usually over a cup of coffee or Coke at a nearby café.

Throughout these interviews and observations, I learned of the many ways of how to obtain products. In Genoa, there are two major sources for purchasing your products: Many of the Senegalese and other African vendors who sell items such as handbags and sunglasses, for example, get these items from Asians. Moroccans, however, primarily buy their goods from other Moroccans in Genoa. Since Moroccans immigrated to Italy about twenty years before Senegalese and other African street vendors, many have been able to setup shops and small businesses in Genoa (Paolocci 2009). This in turn allows Moroccans to buy from "their own people" or their own kin network; people whom they feel they can trust, and people whom they feel will not steer them wrong. Social networks and trust are an important feature of the informal economy-an economy not regulated, and one where law does not generally apply (Stoller 2002, 15-16).

In Genoa, street vendors-at least the ones I spoke withlive in relatively comfortable conditions. For Moroccans, many housing units in the historical center by Principe train station are filled with street vendors. Among the massive amounts of immigrants, however, there are also some vendors who inhabit the poor neighborhoods, like the Begato projects (Magatti and Martinelli 2011).

The immigrants that were studied are all of African descent (and the majority are illegal). In addition, Genoa is still a growing global city, in terms of commerce and population. With that said, it may be hard to generalize this data; however, my hope is that it will unmask some of the similarities shared by the vendors, give a look into their lives, and show how growing global cities can have effects on the vendors, all while providing a framework for future studies and giving more insight into the Genovese street trade.

\section{CONCEPTS AND LITERATURE OVERVIEW}

The main concepts used in this ethnography are globalization, post-industrialization, cultural production, multiple identities and rootlessness, and the "global city" in relation to the vendors. By a global city, I mean one in which there is a large population, along with a globalized hub of culture and commerce, and in the case of vendors, access to improvised opportunities. Using the sociological lens of Paul Stoller's Money Has No Smell, as well as Mark Abrahamson's Global Cites, I will try to examine the immigrant street vendor more thoroughly in Genoa. Additionally, what can a contrast to such an eminent global city as NYC show us about Genoa?

\section{GLOBALIZATION, POST-INDUSTRIALIZATION, AND CULTURAL PRODUCTION}

The street vendor presents an intriguing character in the vast network of globalization. Making the transfer of goods, services, and ideas more possible than ever before, globalization offers unique opportunities to the individual. Postindustrialization, or more precisely-global restructuring-has led to the erosion of the middle-class, and has further polarized the gap between rich and poor (Stoller 2002, 17). The emphasis on knowledge and a concurrent decline in the importance of blue-collar and manual labor creates this faction for would-be vendors. This has thus led to more activity in the unregulated informal economy. With that said, and as Professor Alzetta points out, what once used to be a rather lucrative opportunity has been marginalized somewhat by the increase of immigrants into Europe. He additionally notes a unique kind of hierarchy that exists within this black-market. Would-be vendors, without any start-up capital, may start out as beggars, save up enough to buy small items to sell (i.e. tissues, lighters, bracelets, socks), then eventually work their way up to selling more expensive items, like handbags and sunglasses.

In global cities in general, there is certainly a distinct division of labor. The need in such cities for such highly trained professionals like lawyers, doctors, and bankers in turn leads to the need for positions below these individuals. These increasingly specialized positions may include clerical workers, and other jobs the urban elites demand, generally filled by women. They usually provide only temporary employment, low-wages, and few health benefits. This so-called rise in the "disenfranchised" 
working class, as Stoller (2002) calls it, has led to the rise of jobs outside the formal workplace, and into the informal one (91). A growing number of unauthorized cab drivers, and especially street vendors, attest to this trend.

The global city offers a means to this kind of informal economy. It supplies vendors with a populated city, a heterogeneous population, and a money economy. As Stoller (2002) documents in his research on African vendors in New York City, globalization allows, for example, the funneling of goods, like hats and bags mass-produced in Korea, to be sent to Los Angeles, then shipped throughout the United States, eventually to a broker on Canal Street, who in turn sells them to a street vendor. The massive network that is globalization thus allows for unique opportunities in the global city.

\section{ROOTLESSNESS AND MULTIPLE IDENTITIES}

Another change that experts argue is occurring in the global city is the identity to which one attaches. Some theorists argue that a sense of rootlessness is happening in the globalized world (Abrahamson 2004, 125). These analysts argue that, due to cities becoming so global, people are losing their hometown identities, and instead identifying more as a "citizen of the world." Based on this theory, a street vendor may be seen as rootless to some because he or she is so detached from their homeland the majority of the time. In Stoller's Money Has No Smell, many vendors talk about how much they miss home, how they care for their family, and how they feel no real attachment to the place they are in, further giving evidence to the multiple identities theory $(2002,4)$. The fact that many African vendors intend on returning home, try to respect traditions and their religion, and continue to try to speak their native language waters-down the rootlessness argument.

Looking at the bigger picture, it seems more likely that people may be developing multiple identities, including their "roots" - rather than multiple identities, whilst forgetting their "roots." Building on a different interpretation of Georg Simmel's idea of the "global supermarket," perhaps it is just that the global city "enhances people's ability to shift among multiple identities" (Abrahamson 2004, 127). In other words, this shift allows the immigrant street vendor to pick and choose identities, depending on the role needed or situation at hand.
In Money Has No Smell, for example, Stoller talks to an older man who claims to be a devout Muslim, and who criticizes the "immorality of Americans," their use of foul language, and lack of respect for elders. This man speaks of his faithfulness to his wife (who he has not seen for four years), his pious nature in giving to the poor when he can, and his dedication to religion. When Paul Stoller points out the ironic hat he is selling that says "Fuck Off" on it, and explains its meaning, the vendor-"seeing no dissonance between his views on Islamic morality and his business practices"-switches to his "street vendor identity," and claims that, "We are here in America, trying to make a living... Money has no smell." (2002, XI). The discord among all of these identities is added evidence of several identities-the virtuous Muslim when not at work, and the Americanized, globalized salesman when vending.

Another example would be of the vendor, Issifi, who has a wife back home in Nigeria, but a girlfriend in New York. Psychologically, this other identity may serve a purpose, because it is as if this dissociation lets him reaffirm to himself that what he is doing is acceptable (and to an extent, his cultural background also allows it-Issifi does note that men have more freedom in Africa, in terms of marriage) (Stoller 2002, 3). With such little overlap of networks and connections between the identities, Issifi-and street vendors in general-may confidently switch among identities, without threatening any other personas too much.

\section{NEW YORK CITY: AN “ESTABLISHED” GLOBAL CITY}

When speaking of the structures of a trade market within a global city, it can be safely said that New York City has an "established" one. By established, I mean an informal economy in a global city that has been in practice for well over a decade, has created meaningful connections in the community, has a recognized and strong informal sector, and a vast network among its vendors. A city's urban population also plays a large role in the realm of vending, and as of the 2010 Census, New York's was well over eighteen million. In addition to this, New York City has quite a large immigration population. In fact, it is nearly 36\% (Massey 2010). This, however, does not include the illegal immigrants, which certainly would raise this percentage anyway. 
With a large immigrant population comes a more established global city, due to the amount of diversity and networks formed. And with a more established global city comes a more established informal economy. Because of this, the amount of ethnic enclaves increases, and thus allows would-be immigrants and vendors the opportunity to choose where they would like to go.

What each global city has to offer-demographic-wise and resource-wise-generally affects the items that are sold. New York City street vendors in Harlem, for example, traditionally sell to an African-American population, and their goods are a direct reflection of this (their customers, for example, are generally looking for a way to reconnect to their culture). Items in the Harlem trade section may consist of African "wood" (masks, statues, artwork) and "authentic" kente cloth from Ghana-items that allow the would-be purchaser to connect to their roots.

It can further be argued that New York City is quite an advanced global city, providing numerous neighborhoods of homogeneity (Little Italy, Little Germany, Koreatown, Chinatown, and Harlem among others), intertwined into broad areas of heterogeneity (i.e. tourist hotspots), and consequently more diversity in terms of clientele for the vendors. Vendors in New York City, for example in the Times Square area, may be geared towards a more tourist type of clientele, selling items such as hats and t-shirts with "I Love New York" on them. The freedom for a vendor in NYC to sell in different areas and to different clientele is a testament to the city's top-tier status on the global city continuum.

Establishment also positively correlates to security in some ways. Vendors in Harlem, for example, may setup a market, and all sell on tables, side by side. With this tactic, it is relatively difficult for law enforcement to do anything individually-only to disperse them.

Another prime example of this establishment comes from Stoller's work in New York City. When tough times hit and Issifi was not paid for a shipment of goods, an informal association of street vendors put money together and loaned him what he needed to get started again $(2002,23)$. This vast web of connections and camaraderie among vendors is a result of the vast immigrant presence in NYC. The development of such a safety net, as in Issifi's case, is demonstrative of the informal economy's firm ground here

\section{GENOA DATA: ESTABLISHING A MARKET}

As of 2006 , only about $4 \%$ of Genoa's legal population was made up of immigrants. Home to some 600,000 people, Genoa is still a developing global city (Italian National Institute of Statistics 2006). Genovese street vendors, for example, sell to a more diverse local population, and to a number of tourists. Immigrants do not represent a large number of the local population, and therefore the informal economy is rather weak.

In Genoa, there is really only one "type" of street vendor-the tourist/local population seller (from my month of observation, at least). In certain areas of the historical center, however, it must be noted that some vendors sell traditional Moroccan shoes-babouches - as well as traditional Moroccan garb, but it is generally sold to the local Moroccan population. Additional cultural production is nonexistent.

The number one reason for involvement in the informal economy, regardless of culture, is money. As one street vendor, Abdzurahim Eaoussi, says, "I use this money to support my family; that's why I came here. There are few opportunities to find work in Morocco." Another street vendor I met, under the pseudonym "Mohamed," said, "The money I am able to make here selling is greater than what I would make at a salary job back home." He sends back about one hundred Euros every month in remittances.

Furthermore, in Genoa, not many vendors feel safe selling. When I asked "Mohamed" why he never stays in one place to sell, he said it is because he fears the police. Because there are so few vendors in Genoa, they can easily become outnumbered by police and apprehended. Senegalese and Moroccans in Genoa generally sell alone, or in small groups. In my observations, I have never seen more than five or six Senegalese vendors in close proximity. Moroccans are even more elusive when it comes to groups; I almost always saw them on their own. This shows that Genoa is still a fledgling global city, not quite established just yet. Moreover, in a place like Italy with a long history of nationalism and intolerance, as well as a small amount of immigrants by global city standards, the informal economy is rather weak still.

Likewise, xenophobic laws and policies present another obstacle for the immigrant street vendor. Immigrant dissent in Italy is far from clandestine. The country's current laws make no mistake of their suspicion towards foreigners and their goal of "othering"-that is, dehumanizing and negatively defining the 
immigrant, out-group population. For example, in order to gain citizenship, an immigrant must live in the country for ten years, as well as show proof of a legal occupation for the majority of that time, which is sometimes near impossible, due to discrimination and refusal to hire an undocumented immigrant. In addition to this, the immigrant's children-even if born in Italy-are not guaranteed citizenship, even when they turn eighteen (Campani 2007). This thus deters some would-be immigrants, or at least lessens the impact of a flourishing informal economy through fear.

Due to the aforementioned early arrival of Morrocans into Italy, many of the goods that they sell are indeed reflective of this fact. Items sold in Genoa traditionally include "Ray Bans," counterfeit handbags, tissues, umbrellas, and small mementos; such as mass-produced wooden turtles, and bracelets. A very small amount of Moroccans sell counterfeit bags and sunglasses. The majority sells tissues, socks, umbrellas, and small key chains-all things normally sold in a small store. Many also sell flowers; I actually met a Moroccan immigrant who owned a flower shop on one my observations in the historical center. He was shopping with his wife and kids and when we spoke, he was noticeably proud of his business (one which was started by his father). The Senegalese, on the other hand, really have not established themselves in Genoa yet. Immigrating relatively recently into Italy (not until about 1985), there are few Senegalese shops and shop owners, so their only option, other than Moroccan goods, is to buy from Asians (Hamburg Institute of International Economics 2007).

Throughout my time hanging around vendors in Genoa, I learned that many of them (particularly Moroccan) come and go from Genoa quite often-sometimes even two to three times a year. Partly due to the convenience of travel by bus to Morocco, and partly due to missing family and for religious purposes, there are times when many immigrant street vendors are not present, especially during the Ramadan period. The fact that many immigrant street vendors can be absent at any point in the global city adds to the "establishment" theory. As Genoa grows as a global city in the future, and most likely an important hub for immigration, drastic changes may be seen within the informal realm. Relatively speaking right now, however, the state of the informal economy is not very stable.

\section{GENOA'S GLOBALIZATION}

As many cities have seen over the past century, globalization has allowed the transfer of people, goods, symbols, and ideas all over the world. If any further evidence is needed for the effects of globalization and the global city on the individual, one only needs to go to Via XX Settembre one afternoon to observe the poster boy of these processes: the African immigrant street vendor, in his Italian clothes, carrying his counterfeit sunglasses-most likely from an Asian or Moroccan wholesaler-and eating an inexpensive meal for lunch at the largest fast-food American conglomerate, McDonald's, while ordering in Italian or English. Throughout my observations, I have noticed this type of globalized individual on two occasions. The vendor would come in quickly, put his goods on the floor by the door, take his food in a bag to go, and quickly get back to work. The affordability and quick-style efficiency of McDonald's food aids the vendor in his pursuit of maximum profit on the market.

\section{CULTURE'S ROLE}

There is an old Moroccan saying that goes something along the lines of this: It is better to earn one dirham by commerce than ten dirhams through a salary job. The Moroccan cultural obsession with commerce does not stop there. Additional (roughly quoted) sayings include: "All bad for a woman who roams about, but good for a man who does" and "You can live for one hundred years, but if you do not travel, it might as well be cut in half." All of these phrases support the Moroccan mentality to trade and travel abroad, while emphasizing independence. The people of Morocco often see an individual who travels and supports his family with respect. This, however, consequently puts even more pressure on those not to be deported.

Throughout my investigations, I have also come across an interesting trend in Genoa: Moroccans, in particular, often return home as a sort of retirement. After completing a number of years trading, younger siblings, children, or other family may take over, allowing the elder vendor to return home. When talking with Eaoussi, he made no mistake about wanting to return, saying, "I am taking it easy right now... I plan to return to Morocco in one or two years and let my younger brother take over my position, now that he has his papers.

This concept of filial piety, or as Professor Alzetta cheekily likes to call it, "filial welfare," is part of the immigrant street 
vendor way of life. As Eaoussi notes, he plans on retiring very soon from the street trade. Having done it for fifteen (legal) years, he says he is ready to go back to Morocco shortly. Right now, his younger brothers are getting integrated into the vending market, and they will support him in the future, as he has supported them and his parents. This is seen over and over in the informal economy. With few chances in their home country, these vendors try to make enough money to support their wife and kids, as well as their parents and other family members.

In Genovese-Senegalese trade, as many vendors point out, it is not so much that traveling abroad is encouraged in the society, but rather a "commitment to community," and a need to support one's kin group. The street vendor thus happens to fulfill the criteria of supporting the community and family. In a country where hospitality_known as teranga-and family life and community are highly valued, a position as a street vendor seems like a good fit (Discover Senegal 2008). Being a position in which one must constantly interact with others, create networks, and survive tough times, the Senegalese's cultural background helps them, and their commitment to supporting their family stays the main drive.

In relation to this, Senegalese culture encourages a deep tie to family. In turn, many Senegalese vendors in Genoa often feel homesick and want to return to see their family as well. One vendor, Professor Alzetta noted at the time of these observations, actually just left Genoa to go witness the birth of his first son.

\section{PSYCHE OFTHE GENOVESE STREET VENDOR}

Several street vendors that I have spoken to in Genoa stress the fact that they do not strive to become an Italian citizen since it is nearly impossible for the undocumented immigrant anyhow, and that they do not see themselves in anyway as "Italian." This may be more due to the fact that some of these immigrants experience discrimination and racism in Italy, but it can also relate to their strong ties back home, showing how they are still connected to their roots in some way.

To the immigrant street vendor, the use of multiple identities can be quite beneficial. They may be a father, a devout Muslim, and a street vendor, but all of these may consist of very different networks, with very little overlap. To enhance profit, the vendor may assume the role of "street vendor" in Genoa, use aggressive and sometimes dishonest selling techniques, and temporarily put "devout Muslim" and "father" on the backburner until he returns to his native country.

Moreover in Genoa, street vendors have no problem acting aggressively and trying to make a sale. It is not uncommon for a vendor, for example, to put a bracelet on your un-wanting hand, and then expect payment in return. It is a direct opposite to the other side of these vendors; the side often seen in Mosques in the historical center, in which these vendors respectfully pray and obey the norms.

There was one Moroccan vendor in particular by Piazza De Ferrari who made use of such multiple identities. I noticed him my first day in Genoa, and continued to watch him throughout my stay. He would make his rounds around the fountain, flirting with the women, and putting bracelets on people's hands, usually without asking. I would watch him some afternoons in his relentless pursuit of money, methodically picking out his clients. Sometimes he would just ask for tips. When stores started to close up and the sun began to set, these same vendors would often congregate with each other, presumably talk in their native language-laughing, telling jokes, smoking-switching into a more comfortable and natural identity. Moroccans, most of whom are Islamic, would normally not condone such assertive selling techniques, especially within a religion that has a deep respect for women. For the immigrant street vendor, though, sales correlate to a living and food on the table for their family. That doesn't mean that a vendor loses this other identity, or becomes any less of a Muslim: It is rather put on hold, paused. In fact, there are often overlaps between the street vendor identity and religious identity. A vendor may occasionally leave his goods with a friend during the day so that he can pray, or visit the Mosque in the historical center, just a short walk from the bustling city. This ability to shift back and forth between roles protects the psyche from any conflict that may arise.

The use of multiple identities in the global city thus provides another example of how these places offer unique opportunities for the individual to exploit to their benefit. As seen in Genoa, global cities provide a source of income and a living, rather than a culturally enriching experience that threatens their other identities, or their roots for that matter. 


\section{CONCLUSION}

All in all, global cities provide fertile ground for inimitable social phenomena: It is a place where culture collides and reproduces. Genoa, a growing global city, is establishing itself in Italy as a host for informal economy. As it moves forward on the global city continuum, it will continue to globalize and grow.

Global cities as a whole offer more opportunities around the world to succeed, and thus consequently, more chance to fail. The informal economy is full of a host of risks, and only the wittiest and most street-smart come out on top. The street vendors I met were making more than they would at a salary job back home, however, at the expense of living as an illegal alien and being away from their family. The positive outlooks and spirits of these individuals were incredible, though. Year after year, they work in a foreign country, return home for a couple of months if they're lucky, and then go back to work. The informal economy became their way of life, and in some cases, a "job" passed down to family.

In the beginning, my goal was to uncover some of the universal plights that plague the individuals who inhabit these cities. The topic of street vending and more broadly, informal economies, is one of a vast amount of information and research, and focusing on Genoa, Italy alone presented a wealth of information. To that extent, though, I think I succeeded in my purpose.

As the gap in this world between the wealthy and poor increases at an alarming rate, and as big companies continue the "race to the bottom" in terms of cheap labor, global cities will play host to an increasing number of individuals-people like street vendors in Genoa-looking for success any way they can. With more low-skilled labor and movement in the informal economy to surely come, it will be interesting to see how the networks and connections among these groups develop and form, and the new challenges that these people will face. The global city isn't going anywhere, and will continue to play host to these people.

Among all of this pandemonium, though, it is important to regard these street vendors as human beings and individualsindividuals with values, with family, with culture. Whether their lifestyles are ethically or morally right or wrong is debatable, but at the end of the day, they do this to support their family, and the lure of the postindustrial global city is a hard one to resist. 


\section{WORKS CITED}

Abrahamson, Mark. 2004. Global Cities. New York: Oxford University Press.

Alzetta, Roberto. Interview by author. Personal interview. Genoa, Italy, June 2011.

Belhaj, Imane. 2009. "Morocco among the top ten countries in offshoring sector." Accessed February 12. http://www.magharebia.com/cocoon/awi/xhtml1/en_GB/features/awi/ features/2009/01/07/feature-03

Campani, Giovanna. 2007. "Migration and Integration in Italy: A Complex and Moving Landscape." Accessed June 23. http://www.migrationeducation.org/38.1.html? \&rid=81\&cHash=e5c8e1d629 b6234d84577d1805d9a67b

Colen, Liesbeth, Maertens, Miet, and Swinnen, Johan F.M. 2009. “Globalization and Poverty in Senegal: A Worst Case Scenario?" Paper prepared for presentation at the International Association of Agricultural Economists Conference, Beijing, China, August 16-22.

Discover Senegal. 2008. “Memories of ‘Teranga.'” Accessed June 20. http://www.discoversenegal. com/Memories_Teranga.html

Eaoussi, Abdzurahim. Interview by author. Personal interview. Genoa, Italy, June 27, 2011.

Hamburg Institute of International Economics. 2007. “Focus Migration: Senegal.” Accessed June 22. http://focus-migration.hwwi.de/Senegal.2636.0.html?\&L=1

International Food Policy Institute. 2009. "Agriculture's Critical Role in Africa's Development." Accessed February 12. http://www.ifpri.org/publication/agriculture-s-critical-role-africa-sdevelopment

Italian National Institute of Statistics (Istat). 2006. "Italy in Figures." Accessed June 20. http:// www3.istat.it/dati/catalogo/20070517_00/Italy2007Ing.pdf

Kington, Tom. 2011. "Florence gunman shoots Senegalese street vendors dead." Accessed December 17. http://www.guardian.co.uk/world/2011/dec/13/florence-gunman-shoots-streetvendors.

Magatti, Mauro, and Martinelli, Monica. 2011. “The new urban issue: A journey into the Italian city and its sensitive areas." Accessed January 2. http://www.academicjournals.org/ijsa/ fulltext/2011/March/Magatti\%20and\%20Martinelli.htm. 
Massey, Daniel. 2010. “Immigrants playing a larger role in city's economy." Accessed June 22. http://www.crainsnewyork.com/article/20100113/FREE/100119938\#.TgcSwWW_It0.

Mohamed (pseudonym). Interview by author. Personal interview. Genoa, Italy, June 27, 2011.

Paolocci, Fulvio. 2009. “The Moroccans of San Nicola Varco.” Accessed June 20. http://www. globalpost.com/dispatch/italy/091015/moroccan-immigrants

Pisa, Nick. 2011. “2,500 illegal immigrants a week from North Africa flooding into Europe through Italy." Accessed June 20. http://www.dailymail.co.uk/news/article-2003537/2-500-illegalimmigrants-week-North-Africa-flooding-Europe-Italy.html.

Stoller, Paul. 2002. Money Has No Smell: The Africanization of New York City. Chicago: University of Chicago Press.

US Census Bureau. 2010. “2010 Census Data - 2010 Census.” Accessed June 22. http://2010.census. gov/2010census/data

Voice of America (VOA). 2009. "Italy Pushes For Steps to End Illegal Immigration Problem." Accessed June 22. http://www.voanews.com/english/news/a-13-2009-03-31-voa47-68824532.html

This work is licensed under a Creative Commons AttributionNonCommercialNoDerivs 3.0 Unported License. 